\title{
Normalisasi Kekerasan Seksual Wanita di Media Online
}

\author{
Yofiendi Indah Indainanto \\ Magister Ilmu Komunikasi, Universitas Diponegoro \\ E-mail: yofiendi@gmail.com
}

DOI: https://doi.org/10.21107/ilkom.v14i2.6806

\begin{abstract}
ABSTRAK
Produksi teks yang cenderung memberikan porsi berlebih dalam pemberitaan media, sering kali memposisikan wanita sebagai penyebap masalahan, pemberitaan vulgar dan menyudutkan wanita sebagai korban sehingga hal tersebut menjadi normal dalam komsumsi pembaca. Pandangan feminisme radikal kultural menyebut wanita selalu menjadi korban kekerasan seksual karena adanya dorongan hasrat laki-laki sebagai subjek dan wanita sebagai objek. Metode penelitian ini menggunakan analisis framing Entman dengan paradigma kritis untuk membongkar produksi teks media. Objek analisis mengenai kasus kekerasan seksual Lucinta Luna yang diambil dari empat media, Tribunnews.com, viva.co.id, liputan6.com, dan okezone.com dengan sistem memilih satu berita untuk mewakili. Pemilihan objek didasari korban berstatus publik figure dan diduga transgender. Hasil penelitian menunjukan ketiga media membingkai kasus kekerasan seksual dengan mengeblurkan persoalan utama dan lebih menekankan persoalan drama, sensasi, kontroversi dan identitis korban dengan tampilan perempuan. Penonjolan berita cenderung menyudutkan korban (akrab didunaia malam) dan memposisikan korban sebagai penyebap masalah (berpakaian mini). korban sangat dominan sebagai narasumber dan penggerak narasi berita, sehingga menormalkan kekerasan seksual dengan menyudutkan korban.
\end{abstract}

Kata kunci : Kekerasan seksual, Feminisme Radikal kultural, Analisis Framing, Media Online

\section{ABSTRACT}

Text production that tends to give an excessive portion of media coverage often positions women as problem makers, vulgar reporting and corners women as victims so that it becomes normal in readers' consumption. The view of radical cultural feminism says that women are always victims of sexual violence because of the desire of men as subjects and women as objects. This research method uses Entman framing analysis with a critical paradigm to dismantle media text production. The object of analysis regarding Lucinta Luna's sexual assault cases taken from four media, Tribunnews.com, viva.co.id, and liputan6.com, with the system of selecting one news to represent. The selection of objects is based on the victim's status as a public figure and allegedly transgender. The results showed that all three media frame sexual violence cases by blending the main issues and emphasizing the issue of drama, sensation, controversy, and identity of victims with the appearance of women. The prominence of the news tends to corner the victim (familiar in the night world) and position the victim as a problem driver (dressed in a mini). the victim is very dominant as the source and the driving force of the news narrative, thereby normalizing sexual violence by cornering the victim.

Keywords : Sexual Violence, Cultural Radical Feminism, Framing Analysis, Online Media

\section{Cite this as :}

Indainanto, Yofiendi Indah (2020). Normalisasi Kekerasan Seksual Wanita di Media Online. Jurnal Komunikasi, 14(2), 105-118. doi : https://doi.org/10.21107/ilkom.v14i2.6806

Article History:

Received February, $22^{\text {th }} 2020$

(C) 2020 Yofiendi Indah Indainanto
Acepted April, $2^{\text {th }} 2020$ 


\section{PENDAHULUAN}

Munculnya kasus kekerasan seksual yang dialami publik figure yang diduga transgender Lucinta Luna pada September lalu membuat Media-media online seperti Tribunnews.com, Viva.co.id, dan Liputan6.com, antusias memberitkan dengan berbagai framing untuk menarik perhatian pembaca. Sosok Lucinta Luna yang terkenal kontroversi mengenai identitas dan tindakan dalam menyelesaikan masalah membuat media memberitakan dengan berbagi penekanan, sehingga mampu menghilangkan makna kasus kekerasan dan mengarah pada kontroversi yang dibangun. Citra yang selama ini melekat pada sosok Lucinta Luna dikenal sering menampilkan sisi drama dalam hidupnnya mulai dari pengakukan telah menikah, hamil, mempunyai pacar dan sekarang mengalami kekerasan seksual membuat masyarakat meragukan kasus tersebut, hal tersebut diperparah dengan media yang turut memberitakan sisi drama lucinta Luna. Tampilan (busana, sifat dan tubuh) Lucinta Luna yang mencerminkan wanita memberikan persepsi mengenai wanita sebagai objek kekerasan, sehingga apa yang dialami Lucinta mencerminkan wanita keseluruhan, mulai dari bersikap, dan merespon. Penelitian Utaminingtyas, (2013) yang melihat kekarasan simbolik di media online terhadap fenomenan LGBT pada portal media Republika. LGBT dianggap sebagai penyakit sosial dan menempatkan sebagai tersangka pada pemberitaan. Republika Online melakukan dominasi nilai sebagai bentuk kekerasan simbolik dengan monopoli informasi, tidak memberi ruang bagi pandangan pro-LGBT dan unsur seksualitas ditegaskan. Upaya menormalisasi kekerasa terhadap kelompok transgender ditemukan dalam penelitian Ningsih, (2014) di Film Taman Lawang. Bentuk kekerasan tampak berupa kekerasan verbal, fisik, psikologis dan seksual. Sedangkan bentuk kekerasan yang tidak tampak adalah kekerasan struktural dan kekerasan simbolik. Menurut Rumata, (2020) pembingkaian media terhadap isu LGBT didominasi tentang pandangan pro dan kontra LGBT.
Seringkali media mengekspos sisi korban dalam pemberitaan, sehingga mengarahkan opini korban menjadi penyebap permasalahan, seperti korban menggunakan baju terbuka, korban keluar malam, korban memancing nafsu, dan korban berpergian sendiri. Framing tersebut seringkali mewaranai pemberitaan mengenai kasus kekerasan seksual. Data komnas Perempuan menyebut tahun 2019 terdapat 406.178 kasus kekerasan terhadap perempuan yang dilaporkan dan ditangani selama tahun 2018 (naik dari tahun sebelumnya sebanyak 348.466). Kasus paling tinggi terjadi diranah privat/personal berjumlah 13.568, ranah publik/komunitas 3.915 kasus (28\%), dan ranah negara 16 kasus $(0,1 \%)$ (Https://www.komnasperempuan.go.id).

Artinnya kekerasan seksual dan pelecehan seksual mengalami kenaikan kasus, dengan kata lain, media akan lebih banyak memberitakan kasus tersebut dalam berita, sehingga mempengaruhi pengetahuan publik. Media massa dalam hal ini ibarat pisau bermata dua, disatu sisi media memiliki beberapa fungsi positif, seperti; to inform, to educate, akan tetapi disisi lain informasi yang dihadirkan juga memiliki efek negatif, bahkan bisa jadi pemicu khalayak atau seseorang untuk melakukan hal yang sama dengan tayangan atau informasi yang dilihat (Holilah, 2017:104).

Kasus kekerasan seksual merupakan temasuk kasus pidana berat yang mampu memberikan traumatik korban yang lama. Seringkali dalam pemberitaan media justru melakukan pelecehan secara simbolik dengan penggunaan teks. Pelecehan seksual bermula dari masalah individu, melebar kemasalah kejahatan umum yang bersumber pada nilainilai budaya, sosial, ekonomi, dan politik di dalam masyarakat tersebut, (Adrina, 1995: 38 dalam Supanto, 2004:291). Berdasarkan fenomena tersebut, penelitian ini, fokus melihat bagaimana media memframing berita kasus kekerasan seksual yang dialami Lucinta 
Luna dengan melihat pembandingan framing di tiga media online Tribunnews.com, Viva.co.id, dan Liputan6.com, karena memberitkan kasus kekerasan tersebut?.

Sementara itu, dalam pandangan Feminisme tentang kesadaran penindasan dan hargai diri perempuhan, hingga sebagai gerakan politik yang menuntut kesetaraan seperti yang dijelasakan Bhasin dan Khan (1999: 8), feminisme merupakan perjuangan untuk mencapai kesederajatan/kesetaraan, harkat, dan kebebasan perempuan untuk memilih dalam mengelola kehidupan dan tubuhnya, baik di dalam maupun di luar rumah tangga (Vida, 2011:162). Feminisme radikal merupakan aliran feminis yang melihat penindasan perempuan bukan sebagai akibat dari pengalaman bekerja, atau karena bergabung dengan kelompok perempuan profesional, dan gerakaknnya memastikan hak hukum perempuan, seperti dalam pandangan feminisme radikal, melainkan sistem seks/gender adalah penyebap fundamental dari oprasi terhadap perempuan (Tong, 2010:67-69). Aliran ini perpandangan untuk menghilangakan dominasi laki-laki yang melakukan penindasan, perempuan harus menyadari perempuan tidak pasif dan laki-laki aktif melainkan harus mengembangkan kombinasi keduannya dalam keperibadiaan dan tindakan wanita.

Hasrat laki-laki ingin menguasai wanita memunculkan praktek patriarki, dimana suatu sistem hirarki yang dikembangkan untuk power over yang memastikan kelangsungan hidup komunitas manusia, power over secara cepat menjadi pengalaman orang yang berkuasa, pemegang hukum dalam sistem hirarki. Hasrat tersebut memunculkan konflik antara laki-laki dan perempuan karena sitem patriarki. Untuk menghilangkan sistem patriarki, Marilyn French nilai-nilai feminin harus diintegrasikan kedalam laki-laki yang telah diciptakan ideologi patriarki, sehingga akan memunculkan masyarakat andogini (memadukan sifat feminin dan maskulin) yang individunya akan membangun cinta, kelembutan, kemauan saling berbagi, dan saling menjaga, senatusias dalam merangkul nilai-nilai ketegasan, struktur, rasa miliki dalam sisi maskulin (Tong, 2010:81). Kekerasan, penindasan yang selama ini dihadapi oleh perempuan didasari pada hasrat yang menepatkan laki-laki sebagai subjek dan perempuan sebagai objek. Posisi perempuan yang berada pada dibawah kekuasaan seringkali dijadikan eksploitasi yang menormalkan tindakan laki-laki, seperti kekerasan, pemaksaan yang didasari pada seksual. Kunci aliran feminis radikal kultural harus menghapuskan institusi patriarki seperti industri, keluarga, prostitusi, dan hetroseksual yang diwajibkan.

Perspektif feminisme melihat teks-teks sebagai produksi budaya yang dipengaruhi nilai dalam sistem sosial, politik, ekonomi dan budaya masyarakat (Ida, 2018:192). Artinnya ketika media memproduksi teks tentang berita kekerasan seksual terhadap wanita, mereka bukan hanya memproduksi teks tapi juga nilai sosial yang dominian seperti patriarki. Feminisme radikal kultural digunakan sebagai cara pandang melihat kesus kekerasan yang dialami wanita sebagai upaya meresistensi praktek kekerasan seksual dimanapun yang mendukung dan menormalkan kekerasan seksual laki-laki (Tong, 2010:94), sehingga apa yang dianggap normal pembaca justru menyimpan beragam nilai tentang dominasi laki-laki. Konteks perspektif feminisme radikal dalam penelitian ini, melihat apa yang terjadi dalam teks media lebih menjadikan objek organ seksual untuk dijadikan bahan berita dan penonjolan. Penelitian ini untuk melihat bagaimana kekerasan simbolik kelompok Trangender dibingkai media online.

\section{METODE PENELITIAN}

Penelitian ini, menggunakan metode analisis framing Robert M Entman dengan 
paradigma kertis. Paradigma keritis digunakan untuk melihat hasil produksi teks dari media untuk mengetahui ideologi media mengenai pemberitaan kekerasan seksual. Objek analisis empat berita mengenai pemberitaan kekerasan seksual yang dialami Lucinta Luna meliputi berita Tribunnews. com "Pukuli Lelaki setelah Dilecehkan di Depan Umum, Lucinta Luna: Ada Tenaga Samson dalam Tubuhkus www.viva.co.id "Diremas Bokongnya, Lucinta Luna Curhat Sambil Terisak-isak", dan Liputan6.com "Alami Pelecehan Seksual, Lucinta Luna Dapat Pembelaan". Respon yang tinggi terhadap kasus demi kasus yang dialami Lucinta Luna, seperti identitas, kontroversi, dan sifat laki-laki dalam tubuh wanita, menjadi dasar penelitian ini. Media Tribunews, viva.co.id, dan Liputan6.com dipilih karena memberitakan kasus tersebut dengan judul-judul yang vulgar. Langkah penelitian dimulai dengan menganalisis struktur teks berita masing-masing media, kemudian menganalisis perbandinggan penonjolan untuk mengetahui ideologi media yang menjadi latar belakang penonjolan dilakukan.

\section{HASIL DAN PEMBAHASAN}

\section{Analisis Framing Tribunnews.com}

Pemberitaan

Tribunews.com mengenai kekerasan seksual yang dialami Lucinta Luna dilakukan Tribunnews.com dengan memberitakan pengakuan yang dialami korban yang melakukan perlawanan. Judul berita tersebut "Pukuli Lelaki setelah Dilecehkan di Depan Umum, Lucinta Luna: Ada Tenaga Samson dalam Tubuhku". Bingkai tersebut terlihat dari: Problem identification, Causal interpretation, Moral judgement, dan Teatment recommendation.

Problem identification dalam berita Tribunnews.com menjelaskan kronogi unggah vidio yang menunjukan Lucinta Luna memukul dan menendang pelaku pelecehan seksual. Kronologi berita menjelaskan kejadian yang dialami ketika Lucinta Luna mempromosikan minuman keras dan banyak diminati penggunjung saat pertunjukan sehingga penggunjung pada mabok. Ketika menunggu jemputan dia mengalami pelecehan seksual, namun sepotntan melakukan perlawanan dengan mengejar pelaku, memaki dan mempukul pelaku. Framing berita yang dilakukan Tribunnews lebih menekankan pada respon yang ditunjukan lucinta Luna ketika mengalami pelecehan seksual. Hal tersebut terlihat dari kutipan berita "Ya aku langsung marah, kan pelecehan seksual. Kehormatan wanita saya itu kan benar-benar dong harus aku hormati ya," ujar Lucinta Luna. Penekanan yang dilakukan tribunews dengan menonjolkan respon korban yang melukai pelaku dengan cara menyerang dengan kekerasan fisik cenderung memberikan wacana sikap arogan dari korban. Kata-kata "meluapkan amarahnya, Yah aku langsung marah, tibatiba aku bogem gitu, aku tendang, sampai dia mampus kali,", seakan mengurungai rasa feminis wanita yang sangat sensitif dan mempertetas arogansi korban. Wanita ketika dilecehkan cenderung melakukan respon takut, sedih dan trauma dengan meneteskan air mata tanpa ada serangan fisik. Artinya Tribunews melempar wacana kepada pembaca untuk mempertanyakan tampilan wanita yang melekat dalam diri Lucinta Luna.

Causal interpretation dalam berita tersebut palaku cenderung pasif dan mengakui kesalahan dengan menekankan tidak sengaja. Namun perilaku agresif dari lucinta Luna membangun opini, penyebap permasalahan adalah dirinya. Hal itu dipertegas penekanan tindakan kekerasan, busana lucinta luna yang menggundang nafsu pelaku. Tampilan busana yang digambarkan mengenakan gaun pendek tanpa lengan sehingga menampilkan bentuk tubuh, diduga menjadi penyebap kekerasan seksual. Kutipan berita "Lucinta Luna yang saat itu sedang mengenakan gaun pendek tanpa lengan berwarna putih kemudian langsung meluapkan amarahnya”. Disisi lain 
ditekankan kondisi orang-orang dalam lokasi sedang diluar kendali dengan banyak yang mabok. Artinya media ingin membangun wacana Lucinta Luna menjadi penyebap permasalahan karena orang yang mabok diluar kesadaran. Media dalam kontes ini berusaha mengarahkan pembaca kepada fakta yang menaturalkan keadaan. Normalisasi kekerasan yang dialami oleh perempuan dianggap sebagai sebuah bentuk kewajaran dan natural pada hubungan antara laki-laki (Wood, Julia, 1994:38). Representasi media yang menggambarkan bahwa laki-laki tidak akan bertindak tanpa adanya aksi yang dilakukan wanita terlihat dari berita, seperti wanita berpakaian menggundang nafsu dan laki-laki mabok dan diluar kendali, mempertegas dominasi laki-laki terhadap wanita sehingga mengaburkan persoalan kekerasan dan penindasan terhadap wanita.

Moral judgement, penilaian terhadap berita ini terbagi menjadi dua titik fokus. Pertama, ialah kejahatan seorang pria yang melakukan pelecehan seksual dengan meremas organ vital wanita, dan mengakibatkan korban marah dengan malakukaan serangan fisik. Kedua, ialah perbuatan pelaku akan dianggap wajar dikarenakan dianggap kondisi korban yang memancing nafsu dan kondisi lingkungan yang memungkin tindakan seperti itu normal dilakukan seperti tempat hiburan malam dan kondisi orang sedang mabok minuman keras. Konteks ini, media dapat mendefinisikan perilaku atau nilai yang menyimpang tersebut bukanlah sesuatu alamiah yang terjadi dengan sendirinnya, artinnya hal tersebut dikontruksikan yang secara aktif mendefinisikan peristiwa dan realitas sehingga membentuk kenyataan apa yang layak, apa yang baik, apa yang sesuai dan apa yang dipandang (Eriyanto, 2008:122-123). Sebut ketika lingkungan kejadian yang dekat dengan dunia malam, korban berpakaian terbuka membentuk realitas bahawa wanita yang berada dalam lingkungan ini dianggap menyimpang, sehingga ada kewajaran korban mengalami kekerasan seksual. Namun ada bingkai lain yang mengarahkan pembaca pada sisi drama dengan respon korban yang melakukan perlawanan dengan melakukan kekerasan fisik, hal ini berbeda dengan kontruksi yang selama berkembang, dimana wanita biasanya pasif justru menjadi ageresif yang selama ini digambarkan terhadap lakilaki. Artinnya media berusaha menonjolkan isu lain dalam berita.

Teatment recommendation yang dilakukan dalam berita tersebut, Lucinta Luna melakukan tindakan damai dan memaafkan pelaku pelecehan seksual. Lucintalunca tidak membawanya ke jalur hukum karena permintaan maaf pelaku yang diterimanya, dan lebih menekankan sebagai manusia untuk saling memaafkan "Kan kesel banget. Akhirnya KTP-nya ditahan sama Abash, terus kemudian kami ke rumahnya di daerah Sawah Besar, minta maaf dia nangis-nangis," pungkasnya. Meskipun berakir damai, Tribunews dalam memberitakan terkesan menderamatisir dengan memasukan kutipankutipan yang berlebihan seperti "dia nangisnagis", sehingga memberikan wacana berita tersebut bagian dari senasi yang dibangun Lucintaluna. Memang media berusa memproduksi teks agar membuat pembacanya memiliki kesan dan makan dalam mengkonsumsi konten. Penekanan ini menjadi senjata media untuk mengarahkan pada realitas yang akan dibangun, dimana sisi kontroversi korban jauh lebih menarik dibanding dengan nilai humanis yang memaafkan pelaku.

\section{Analisis Framing Viva.co.id}

Pemberitaan yang dilakukan Viva.co.id mengenai kekerasan seksual yang dialami Lucinta Luna menjadi telihat fulgar dengan menunjukan organ vital dalam judul berita "Diremas Bokongnya, Lucinta Luna Curhat Sambil Terisak-isak”. Pemilihan judul yang 
vulgar dengan objek vital dijelaskan, memperlihatkan media tersebut tidak melindungi hak korban dalam pemberitaan.

Problem identification, menjelaskan kondisi mental Luncinta Luna yang merasa sedih berdasarkan postingan di inststory yang disebapkan akibat pelecehan yang dialami dirinya. "Kamu perempuan tiba-tiba dipegang, diremas, aku langsung marah dan si Abas langsung nonjok di situ, " kata Lucinta sembari terisak. Meskipun penonjolan berita yang dilakukan viva.co.id lebih kependekatan korban yang seorang wanita, namun tidak serta-merta menghilangkan sisi arogan korban yang tidak lazim. Disisi lain penggunaan kata dalam penegasan kutiapn "kata Lucinta sembari terisak", menjadi sisi lain yang masih mengangkat dramtisasi persoalan dengan tindakan yang berulang-ulang. Kasus tersebut mengukuhkan budaya partiarki yang menyebut, tubuh perempuan dikonsumsi sebagai objek pandangan, objek sentuhan, objek seksual, objek hasrat laki-laki, dan objek ideologi. Secara umum, perempuan dikonsumsikan dan diprsepsikan sebagai objek dalam arti harfiahnya adalah penerimaan tindak/laku (Prabasmoro, 2007:80). Artinnya wanita diposisikan sebagai objek untuk dominiasi laki-laki yang dikonsumsi melalui tubuh. Media berusaha memperkuat dominasi budaya tersebut dengan menekankan pada penggunaan bahasa dan penonjolan isu, seperti kutipan "dipegang, diremas" yang mengarah pada tindakan objek tubuh yang dikonsumsi. Dampak tindak/laku dari korban mengceritakan kronologi kasus justru memperkuat objek ideologi wanita selalu menjadi bagian dari budaya patriarki.

Causal interpretation berusaha mengajak pembaca berada pada situasi korban yang mengalami trauma akibat mengalami pelecehan. Serta mengajak pembaca merasakan berada pada korban bahwa wanita akan sedih dan tidak diterima dengan tindakan pelecehan yang dilakukan laki-laki. Asumsi tersebut diperkuat dengan penekanan pada beberapa kata yang digunakan dari persfektif korban. Tindakan kekerasan seksual membuat korban menanggung beban fisik dan posikologis. Kondisi ini menciptakan ketidakberdayaan korban yang merampas hak kedamaian, dan menimbulkan ketakutan, sehingga membuat korban membutuhkan penanganan kusus.

Moral judgement melihat berita tersebut, mengajak pembaca bahwa korban pelecehan akan mengalami trauma dan perasaan sedih yang berkepanjangan. Namun, berita juga mempertegas wanita bisa melakukan perlawanan ketika terjadi pelecehan seksual yang dialami. Dalam situasi terdesak wanita akan melakukan perlawanan meskipun itu dianggap aneh dan bertentangan dengan realitas yang berkembang. Namun, dalam representasi yang ditampilkan media dari teks "Ini kejadian malam penuh enggak disangka-sangka. Aku dilecehkan sama orang tak dikenal enggak ada basa-basi minta foto atau nyapa apa lah. Malah remas-remas gue. Perempuan mana yang enggak ngamuk sampai dilecehin kayak gini," tulisnya dalam video tersebut, terlihat ketidakadilan yang ditampilkan meskipun itu dalam kutipan langsung terlihat dari "perempuan mana yang enggak ngamuk sampai dilecehin gini", artinnya media membangun makna wanita lain akan melakukan kekerasan balik terhadap pelaku. Pembelaan negatif bagian dari ketidakadilan yang mengarah pada pembentukan stereotipe wanita idenik keras.

\section{Treatment recommendation dalam} berita mengajak pembaca untuk melawan ketika mengalami pelecehan seksual. Selain itu berita tidak menjelaskan penyelesaian masalah dan cenderung memberitahu pembaca penegasan pembelaan korban. Pada keadaan seperti ini, tanpa adanya penyelesaain maka itu dianggap bukan masalah yang serius untuk diselesaikan, terlebih hanya pada sisi korban jurnalis memberitakan. Dapat dilihat pelecehan 
seksual dalam konteks ini bukanlah masalah individu semata, tetapi lebih jauh lagi merupakan masalah kejahatan yang berakar pada nilai-nilai budaya dan sosial. Orang yang dianggap kontroversi hidupnya penuh dengan sensasi, setidaknya streotip seperti itu yang tergambar dalam berita.

\section{Analisis Framing Liputan6.com}

Pada pemberitaan kekerasan seksual Lucinta Luna, Liputan6.com memilih egel tentang simpati dari pembaca seperti dalam judul berita "Pelecehan Seksual, Lucinta Luna Dapat Pembelaan”. Ada nilai pembelaan yang diangkat tentang kasus tersebut, artinnya liputan6.com berani mengambil bingkai dari perspektif pembaca. Sumber berita yang diambil liputan6 dari aktivitas media sosial.

\section{Problem identification tentang} pembelaan yang dilakukan nitizen dengan menyayangkan tindakan yang dilakukan pelaku. Adanya penegasan tentang transgender yang dilakukan nitizen, memberikan wacana tindakan pelecehan tidak seharunya terjadi. Meskipun diawal berita lebih menjelaskan kronologi kejadian dan respon korban, namun perhatian pembaca tetap pada pembelaan yang dipertegas dalam judul berita. Pembelaan tersebut Akun @aintyourmar berkomentar, "Uhm gini, diluar segala kontroversi yang dia buat, dia ga berhak untuk dilecehkan, lelaki maupun perempuan, tak berhak dilecehkan, mereka manusia, sayangnya manusia itu tak diberi rasa kemanusiaan oleh sesama manusia." Pada perinsipnya penulisan berita menggunakan konsep piramida terbalik, dimana hal yang sangat penting menjadi pembahasan utama yang diikuti dengan penjabaran "bagaimana" yang mendukung berita. Artiannya ketika pemilihan judul tentang pembelaan, seharunnya di bagian lead dan awal cerita berita menekankan pemberitaan berkaitan dengan judul.
Penempatan pembelaan yang terletak di akhir berita, memposisikan korban pelecehan seksual yang pernuh kontoversi terlebih trangender tidak perlu dibela.

Causal interpretation berusaha mengajak pembaca untuk mengecam pelaku pelecehan seksual, meskipun Lucinta Luna selalu identik dengan senasionalnnya dan penuh kontroversi, namun bukan berarti pelecehan seksual normal dilakukan. Transgender dalam perkembangannya sulit diterima masyarakat karena diangap menyimpang dan bertentangan dengan kodrat. Individu transgender banyak mengalami ejekan, cibiran, kekerasan, pengucilan dari orang-orang di sekitarnya. Walaupun ada beberapa orang disekitarnya yang bisa memahami kondisinya dan menerimanya, namun sebagian besar masyarakat akan menolaknya, bahkan mereka mungkin akan merasa jijik dengan seorang transgender(Siti et al., 2016:91). Permasalahan tersebut membuat Lucinta Luna justru lebih banyak mendapat ejekan dibanding dengan simpati dari kasus yang dialami, mesipun ada penegasan "Aku sebagai wanita bener-bener sedih. Ini namanya pelecehan seksual”, namun itu tidak mengurangi pendangan orang tentang trangender, hal tersebut terlihat dalam akhir berita "Mau dia cewek atau cowok, pelecehan tetap tidak dibenarkan. Kok ini korbannya malah dibully. Miris."

Moral judgement berita ini membentuk opini pembaca yang mempertannyakan status identitas yang dimiliki Lucintaluna, hal itu terlihat dari kutipan narasumber dan body berita "Terlepas dari kontroversi Lucinta Luna sebagai seorang transgender”. Karena sosok yang kontroversi Lucinta Luna sering kali mengalami pelecehan ditambah tindakan yang dilakukan kepada pelaku mempertegas kontoversi yang selama ini melekat. Liputan6.com membingkai berita dengan mengeblurkan persoalan mengenai kekerasan dan mengarahkan ketertarikan pembaca 
mengenai identitas korban yang trangender. Hal tersebut terlihat dari pemilihan komentar nitizen "Mau dia cewek atau cowok, pelecehan tetap tidak dibenarkan". Jika fokus utma tentang pembelaan, harusnya memilih komentar nitizen yang lebih subtantif mengenai kasus kekerasan seksual dibanding dengan identitas.

\section{Treatment}

recommendation,

penekanan penyelesaian permasalahan mengajak pembaca untuk saling menghargai terlepas korban adalah laki-laki atau perempuan dan mengecam tindakan pelecehan. Dukangan harus dilakukan untuk korban bukan justu dibully. Artinya ada kesadaran korban kekerasan seksual adalah tindakan yang sangat berdampak buruk pada korban.

\begin{tabular}{|c|c|c|c|}
\hline $\begin{array}{l}\text { Analisis } \\
\text { Framing }\end{array}$ & $\begin{array}{c}\text { Tribunnews. } \\
\text { com }\end{array}$ & $\begin{array}{l}\text { Viva. } \\
\text { co.id }\end{array}$ & $\begin{array}{l}\text { Liputan6. } \\
\text { com }\end{array}$ \\
\hline $\begin{array}{l}\text { Problem } \\
\text { identific } \\
\text { ation }\end{array}$ & $\begin{array}{lr}\text { Lucinta } & \text { Luna } \\
\text { memukul dan } \\
\text { menendang pelaku } \\
\text { pelecehan seksual }\end{array}$ & $\begin{array}{l}\text { Kondisi } \\
\text { kesedihan } \\
\text { korban } \\
\text { pelecehan }\end{array}$ & $\begin{array}{l}\text { Penegasan } \\
\text { trangender } \\
\text { mengalami } \\
\text { pelecehan }\end{array}$ \\
\hline $\begin{array}{l}\text { Causal } \\
\text { interpr } \\
\text { etation }\end{array}$ & $\begin{array}{l}\text { Palaku cenderung } \\
\text { pasif dan mengakui } \\
\text { kesalahan dengan } \\
\text { menekankan tidak } \\
\text { sengaja. Korban } \\
\text { menunjukan } \\
\text { perilaku agresif } \\
\text { dan menjadi } \\
\text { penyebap } \\
\text { permasalahan }\end{array}$ & $\begin{array}{l}\text { Mengajak } \\
\text { pembaca } \\
\text { pada } \\
\text { situasi } \\
\text { korban }\end{array}$ & $\begin{array}{l}\text { Gambaran } \\
\text { kelompok } \\
\text { trangender } \\
\text { mengalami } \\
\text { diskriminas } \\
\text { i malalui } \\
\text { pelecehan }\end{array}$ \\
\hline $\begin{array}{l}\text { Moral } \\
\text { judgem } \\
\text { ent }\end{array}$ & $\begin{array}{l}\text { Pertama, kejahatan } \\
\text { seorang pria } \\
\text { melakukan } \\
\text { pelecehan seksual. } \\
\text { Kedua, perbuatan } \\
\text { pelaku dianggap } \\
\text { wajar dikarenakan } \\
\text { korban yang } \\
\text { memancing nafsu } \\
\text { dan kondisi } \\
\text { lingkungan } \\
\text { penyebapnya. }\end{array}$ & $\begin{array}{l}\text { Korban } \\
\text { pelecehan } \\
\text { akan } \\
\text { mengala } \\
\text { mi trauma }\end{array}$ & $\begin{array}{l}\text { Mempertan } \\
\text { nyakan } \\
\text { status } \\
\text { gender } \\
\text { korban }\end{array}$ \\
\hline $\begin{array}{l}\text { Teatme } \\
\text { nt } \\
\text { recom } \\
\text { mendat } \\
\text { ion }\end{array}$ & $\begin{array}{l}\text { Melakukan } \\
\text { tindakan damai dan } \\
\text { memaafkan pelaku } \\
\text { pelecehan seksual. }\end{array}$ & $\begin{array}{l}\text { Mengajak } \\
\text { pembaca } \\
\text { melawan } \\
\text { pelaku } \\
\text { kekerasan } \\
\text { seksual }\end{array}$ & $\begin{array}{l}\text { Mengajak } \\
\text { pembaca } \\
\text { saling } \\
\text { mengharga } \\
\text { i keputusan }\end{array}$ \\
\hline
\end{tabular}

Tabel: Perbandingan framing ketiga media

\section{Perbedaan Penonjolan dan Seleksi Isu Antar Media}

Berdasarkan Faming dari ke emat elemen dasar yang dikemukan Robert N Entman, ada perbedaan mendasar bagaimana media menonjolkan isu dan sekeleksi isu berdasarkan dimensi besar framing Entman.

Media Tribunnewes.com pada dimensi seleksi isu menyeleski fakta dengan meperlihatkan kemapuan korban dalam merespon tindakan akibat pelecehan. Kemapuan tersebut didapat dari ungkapan korban yang mengaku mendapatkan tenaga untuk melawan pasca kejadian. Kesan dari seleksi ini memberikan pengamburan pada keronologi dan fokus pada pelawanan korban. Sedangkan pada dimensi penonjolan isu pada kalimat-kalimat yang menggambarkan pengakukan seperti "tendang, tenaga Samson", dan judul berita "Pukuli Lelaki setelah Dilecehkan di Depan Umum, Lucinta Luna: Ada Tenaga Samson dalam Tubuhku”, artinnya media tribunnews.com lebih menekankan pada dramatisasi kejadian.

Media Viva.co.id pada dimensi seleksi isu, Viva menekankan pada pendekatan korban yang mengungkapkan kesedihan menjadi korban pelecehan seksual. Seleksi ini terlihat dari alur berita yang mengarahkan pada kondisi korban yang alami trauma. Pemlihan narasumber yang mengakan sisi korban mempertegas tentang seleksi isu lebih pada menarik simpati. Sementara untuk penonjolan aspek isu Viva lebih vulagar menampilkan pelecehan yang dialami korban, hal tersebut terlihat dari judul, "Diremas Bokongnya, Lucinta Luna Curhat Sambil Terisak-isak". Penggunaan kata dengan menyebut organ vital, seolah-olah membuat objek pelecehan tersebut tidak bernilai dan tidak melindung hak korban. Artinnya Viva.co.id lebih menjadikan bentuk pelecehan sebagai bentuk komoditas berita tanpa menimbulkan efek edukasi. Dalam industri media, tubuh wanita tidak ubahnnya seperti 
barang dagangan, yang dipaksa untuk ditonjolkan dalam narasi berita agar menjadi pemikat untuk dijual. Tanpa menonjolkan aspek tertentu berita hayan kumpulan kata tanpa sensasi. Celakannya, narasi tersebut justu menjadikan pembaca tertarik, artinnya media memberikan gambaran tentang berita ideal tentang kekerasan. Sisi penasaran yang ada dalam individu, diekspolitasi media untuk dijadikan pemikat.

Media liputan6.com, pada dimensi seleksi isu, menekankan pada persoalan identitas yang melekat pada Lucinta Luna sebagai korban. Selain penjelasan tentang kejadian perkara kejadian, Liputan6.com menekankan pada identitas korban, hal tersebut didukung dengan pemulihan kutipan narasumber yang memberikan gambaran transgender sehingga pembaca lebih fokus pada persoalan tersebut. Meskipun judul berita menekankan pada pembelaan, namun isi berita berbeda maksud. Sedangkan dimensi penonjolan terlihat komentar nitizen yang mengarah pembelaan namun tetap mempertannyakan identas seksual korban. Hal tersebut seperti "Mau dia cewek atau cowok", "terlepas dari sosok Lucinta Luna seorang tansgender".

Ada kekakuan pengetahuan dan makna tentang sifat-sifat feminim yang diletakan pada wanita dan maskulin pada lakilaki yang tergambar dalam pemberitaan media. Jika feminis dan maskulin terjadi diluar sifat yang semestinnya akan mengalami penghinaan, cemoohan, caci-maki, bahkan pencekalan. Narasi seperti ini menjadi bagian konsumsi media yang akan memberikan pemahaman tentang gender itu sendiri. Misal, wanita akan bersikap lembut karena sifat feminimnnya, maka tidak dianggap wanita yang baik jika melakukan kekerasan, pemukulan dan mengeluarkan kata-kata kotor. Seksisme tersebut yang menjadi pengetahuan dan pemahaman dalam kehidupan.
Penojolan media diatas yang mengekspos korban dengan berbagai egel, mulai dari bentuk drama, identitas, kekerasan fisik, memperkuat kekakuan tentang pemahaman feminim dalam wanita. Pemilihan kata dan penjambaran justru lebih mengangkat keanehan yang ditimbulkan dari korban. Narasi seperti itu membuat media menyudutkan korban seperti dalam kasus Lucinta Luna.

Media membentuk narasi melalui penonjolan teks untuk membangun nilai moral yang diperdepatkan dalam imajinasi pembaca, sehingga mampu memutuskan tentang kapasistas moral layak atau tidak. Menurut Johnson (1993), narasi bisa memberi kita tiga wawasan yang melibatkan imajinasi pembaca tentang pengakuan kualitas moral masalah, perspektif yang berbeda, dan konsekuensi untuk semua orang yang terlibat. Pertama, narasi dapat menawarkan wawasan tentang apa yang memiliki kualitas moral. Misal, Lucinta Luna melakukan tindakan kekerasan terhadap pelaku, apakah moral dari tindakan tersebut tepat, sehingga mengarah pada kualaitas moral Lucinta Luna dalam ruang imajinasi pembaca. Kedua, narasi dapat menawarkan wawasan tentang berbagai perspektif atau bentuk musyawarah tentang masalah moral. Misal, apakah yang dilakuakan korban dalam teks berita sesuai dengan nilai moral, sehingga ketika pembaca mengkonsumsi teks tidak sesuai dengan nilai moral yang umum akan mengarah pada evaluasi. Ketiga, narasi menawarkan wawasan tentang berbagai konsekuensi bagi mereka yang terlibat dalam situasi khusus. Wawasan motivasi, perasaan dan karakter orang lain sangat penting untuk keputusan moral akhir (Krijnen, 2011:55-57), Artinya melalui penonjolan teks pembaca akan memutusukan moral Lucinta Luna yang ditampilkan teks akan mengarah pada sikap pembaca (peduli atau mengecam) terhadap penilaian moral yang dilakukannya. Sejauh ini media lebih menyudukan korban dengan 
tindakan kekerasan terhadap pelaku sehingga mengarahkan pembaca pada evaluasi moral dan lebih mengecam korban dibanding pelaku.

\section{Ideologi Media dalam Membentuk Berita kekerasan Seksual}

Media mempunyai strategi wacana tersendiri dalam memaknai peristiwa tersebut. Frame menentukan bagaimana fakta diambil, dilakukan, bagaimana hasil wawancara diperlakukan, bagaimana ditulis dan ditempatkan dalam berita di website. Terlihat dari ke ketiga berita diatas yang diambil dari empat media berbeda masih menunjukan kondisi kelompok minoritas Transgender diperlakukan tidak adil dalam pemberitaan. Mulai dari mengeblurkan persoalan pelecehan, menampilkan sisi drama, menyebutkan oragan vital dan pengungkapan identitas melalui teks. Menurut Hall (1981), Ideologi mengacu pada segala gambaran, konsep gagasan yang menjadi pijakan untuk digunakan menyajikan, menginterpretasikan, mengerti atau menerima aspek-aspek keberadaan masyarakat. Idologi mencakup bahasa, konsep dan kategori yang berasal dari berbagai masyarakat dalam memahami lingkungan (Morissan, 2013:165). Ideologi yang berkembang di Indonesia mengganggap kelompok LGBT merupakan tindakan menyimpang. Atas dasar tersebut Ideolgi media sangat dipengaruhi sistem politik yang dianut negara yang memposisikan LGBT sebagai kelompok minoritas. Indonesia sangat kental budaya kulural timur dan agama, sehingga LGBT diangap berbenturan dengan nilai keduannya. Dampak dari idelogi tersebut akan menseleksi dan pemilihan fakta dari realitas Yang berkembang. Kasus kekerasan seksual Lucinta Luna, memposisikan fakta pada pemilihan ideologi yang berkembang, sehingga sangat tercemin posisi korban dalam teks. Dalam memproduksi realitas yang dianggap memiliki nilai penting oleh kebijakan media dibanding dengan realitas lainnya, bersamaan dengan itu, akan ada penekanan, penonjolan, maupun argumentasi dalam rangka mengonsumsi sebuah realitas menjadi berita yang akan dipublikasi. Sebaliknya akan ada fakta-fakta yang dikesampingkan, disembunnyikan, maupun diabaikan (Nasrulah, 2018:77). Dalam hal tersebut media akan membentuk idologi yang terlihat dari teks yang ditampilkan.

Menurut Tom Douglas (1995:39) menyebut bahawa proses pengambinghitaman terjadi ketika tidak ada itikad baik untuk membongkar penyebap pokok permasalahan yang tidak menyendangkan, sehingga pihak dominan dan memiliki kuasa untuk memilih orang untuk disalahkan. Umumnnya orang yang tidak disukai dan diyakini berbeda atau lyan ((Jurnal Perempuan, 2013:62). Berita kekerasan pada dasarnnya fokus tentang tindakan kekerasan yang melanggar hukum dan mengancam wanita. Konteks pada pemberitaa Lucinta Luna media justru membuatnya bias dan fokus pada menyudutkan korban dengan dalih, korban penyebap masalah, menggunakan pakaian minim, berada dilingkungan malam dan melakukan pemukulan terhadap pelaku. Bingaki tersebut menjadi dominan dalam narasi berita. Artinnya pengaruh relasi kuasa dan pihak yang dianggap dominan menganggap kasus kekerasan seksual tersebut aneh karena melewati batas norma. Fokus ini yang mengarah media melakukan kekerasan secara tekstual dengan pemilihan kata (bokongnya, menangis tersendu-sendu, kekuatan samson) menjadi penonjolan. Posisi pelaku menjadi pasif karena komposisi berita lebih dominan korban. Ada bentuk marjinalisi dan obyektifikasi perempuan yang dikontruksikan lewat permainan bahasa yang memperoduksi kekerasan lewat pemilihan diks, plabelaan, dan penyusunan kalimat. Artinnya pemilihan kata untuk berita memperkuat peraktek kekerasan secara simbolik. Kekerasan simbolis terjadi dalam 
bentuk representasi mengenai perempuan di ruang publik, sebuah norma mengatur bagaimana tubuh harus ditampilkan dalam kehidupan sosial. Implikasi dari norma sosial yang menargetkan tubuh perempuan sebagai objek pengamatan masyarakat adalah pembenaran yang kian subur atas kekerasan. Logika ini pada akhirnya tidak sekadar sebuah struktur pikiran yang misoginis tetapi termanifestasi dalam praktis sosial. Pola demikian akhirnya membuat pengalaman perempuan menjadi lemah di dalam sebuah proses hukum" (Jurnal Perempuan 2016: 206 dalam Agustin, 2018:117).

Kemunculan wanita dalam teks berita cenderung stereotipikal yaitu sebagai korban tanpa menjadi penyelesai masalah. Pada saat media memberitakan wanita sebagai korban, pada saat itu juga media menyudutkan wanita untuk dikorbankan dalam narasi berita. Setidaknya itu yang tergambar dari ketiga berita di empat media. Menurut Klapp (1964) perempuan menjadi korban memiliki dua kategori, pertama good victim dan bad victim. Good victim memunculkan rasa simpati dikalangan pembaca, dilihat dari posisi korban yang mengalami ketidakberdayaan, ketidakmampuan untuk melawan, kelemahan fisik dan mental akan sering ditonjolkan dalam korban. Sebaliknnya, Sosok bad victim pihak yang provokatif, tidak disukai dan tidak memunculkan simpati. Dalam 3 narasi berita yang ditampilkan sangat sedikit peran good victim yang dibentuk media untuk Lucinta Luna, hanya terilhat korban mengalami trauma butuh simpati dan perlindungan. Lucinta Luna digambarkan wanita yang pekerja keras dan tangguh. Sosok seperti itu muncul secara tersirat dari teks dan memposisikan sebagai korban. Namun sosok Bad Victim sangat dominan. Lucinta Luna digambarkan sosok agresif, keras, hina, dan akarap dunia malam. Stigma tersebut diperkuat dengan latarbelakang pekerjaan dimana Ia menjual minuman keras, bekerja didunia hiburan dan akarap dengan dunia hiburan yang gelamor. Wajar saja publik menilai apa yang dilakukan Lucinta Luna hanya sensasi. Peran tersebut dijadikan media untuk membentuk konsep wanita baik dan tidak baik, sehingga dalam banyak berita lebih berkutik pada seksualitas wanita dalam teks dan memunculkan wanita dalam pusat narasi berita yang memberikan gambaran kategori wanita good vicitim itu seperti pulang tepat waktu, berada dilingkungan baik, berpakaian tertutup dan menghindari dunia malam, sedangkan bad victim digambarkan wanita bekerja dimalam hari, berpakaian terbuka dan akrab didunia hiburan. Penggambaran inilah yang akan membentuk realitas dan kereteria wanita ideal.

Tampilan realitas yang dianggap penting bukan persoalan pelecehan seksual yang dialami, melainkan pada bentuk kontoversi korban yang tampilannya berbentuk wanita namun sifat dan karakter menujukan laki-laki. Penekanan ini terlihat dari ketiga berita yang ditampilkan dalam pespektif korban, sehingga mengaburkan fakta tentang kekerasan seksual yang dilakukan pelaku adalah salah. Penonjolan aksi perlawana korban, membuat media memframe berita yang mengarah pada identitas korban bukan pada pembelaan, hal tersebut terlihat dari kutipan berita liputan6.com yang mengambil komentar nitizen menonjiolkan identitas seksual. Minoritas selalu menerima perlakuan yang tidak sama dengan masyarakat dominan, mereka mengalami marginalisasi seperti, kekerasan, dan diskriminasi dari orang lain. Sebagai kelompok minoritas dalam masyarakat, seorang transgender akan menerima akses yang terbatas dari beberapa pelayanan masyarakat yang ada (Siti et al., 2016:83). Hal tersebut terlihat dalam posisi pemberitaan media yang menyudutkan transgender. Pembaca akan memilki gagasan esensialis yang melekat dalam dikotomi seks gender melampaui, jenis kelamin dipandang sebagai salah satu struktur yang 
menginformasikan identitas (Krijnen, 2017:9), sehingga jika transgender menjadi titik dominan teks, pembaca akan membangun imajinasi tentang identitas tersebut. Pemberita-pemberitaan tersebut membuktikan bahawa media belum menerima kelompok minoritas menjadi bagian dari kultural masyarakat, namun masih mengganggap kelompok yang menyimpang dari kultur masyarakat, mulai dari nilai kebudayaan hingga moral masih menjadi pertentangan. Media mengambil peran dalam menciptakan wacana pertentangan tersebut dari contoh berita kekerasan seksual Lucinta Luna. Seperti penelitian Indainanto, (2020) ketika sebuah individu berbeda dengan kelopok mayoritas akan mengalami bullying yang tidak memandang kedudukan seseorang. Transgender sebagai kelompok minoritas dan berbeda budaya timur, terus mengalami penolakan.

\section{PENUTUP}

Kasus kekerasan seksual yang korbannya Lucinta Luna mendapat perhatian media untuk mengangkat pemberitaan dari berbagai sudut pandang. Sosok penuh kontroversi yang melekat mulai dari sikap dan persoalan identitas ditambah perkejaannya didunia huburan, membuat media lebih menarik memberitakan yang fokusnnya bukan pada kekerasan seksual melainkan sosok yang melekat pada diri individu. Pemberitaan Tribunnews.com memberitakan dari sisi drama kejadian dimana korban memiliki kekuatan melawan. Viva.co.id memberitakan dengan penekanan pada penggunaan kata vulgar untuk menarik perhatian dan pendekatan kesedihan pelaku. Liputan6.com menekankan kepedulian nitizen yang dikemas dalam persoalan identitas gender korban. Kekerasan seksual dengan korban wanita cenderung menjadikan tubuh sebagai bahan berita dan memposisikan wanita sebagai sumber masalah, dan dipersalahkan dalam pemberitaan. Hal tersebut terlihat dari dominasi wanita dalam berita yang diungkapan mulai dari latarbelakang pekerjaan, tampilan dan karakter personal. Bingkai tersebut mengukuhkan bahwa kelompok dominan yang memiliki relasi kuasa mampu memberikan memposikan wanita sebagai korban good victim dan bad victim.

Keseluruhan perbandingan framing media online menonjolkan korban menjadi penyebap permasalahan dengan menekankan pada Bad victim yang diberitakan arogan, keras, busana menggoda, dan lingkungan yang akrab didunia malam. Pemberitaan tersebut memperkuat Ideologi media dimana tunduk pada relasi kuasa dan kental budaya kultural yang menganggap wanita identik dengan dunia huburan dan dunia malam dianggap tidak baik, terlebih yang pelakunya trangender.

\section{DAFTAR PUSTAKA}

Agustin, M. R. dan H. (2018). Representasi Kekerasan Seksual Terhadap Perempuan Di Situs Berita Tirto . Id. 02, 115-134.

Eriyanto. (2008). analisis Framing kontruksi ideologi dan politik media (Cetakan V). Yogyakarta: PT Lkis Pelangi Aksara.

Hamid, M. A. C. W. F. (2013). Teori Komunikasi Massa. Jakarta: Ghalia Indonesia.

Https://www.komnasperempuan.go.i d/read-news-lembar-fakta-dan-poinkunci-catatan-tahunan-komnasperempuan-tahun-2019. (n.d.). Read News. Retrieved December 11, 2019, from https://www.komnasperempuan.go.i d/read-news-lembar-fakta-dan-poinkunci-catatan-tahunan-komnasperempuan-tahun-2019

Ida, R. (2018). Metode Penelitian Studi Media dan kajian Budaya (cetakan ke). Jakarta: Prenadamedia Group.

Ilah Holilah. (2017). Dampak Media 
Terhadap Perilaku Masyarakat. Jurnal Uinbanten.Ac.Id, 103-114.

Indainanto, Y. I. (2020). Relasi Politik, Bullying dan Etika Mengenai Isu “" Muslim Uighur " di Media sosial. 4(1). https://doi.org/10.30596/interaksi.v4 i1.4014

Jurnal Perempuan. (2013). Gender dan Teknologi. Jakarta: Yayasan Jurnal Perempuan.

Krijnen, T. (2011). Engaging the Moral Imagination by Watching Television: Different Modes of Moral Reflection 1. 8(2), 52-73.

Krijnen, T. (2017). Feminist Theory and the Media. The International Encyclopedia of Media Effects, (1991), 1-12. https://doi.org/10.1002/9781118783 764.wbieme0096

Nasrulah, R. (2018). Khalayak Media, Identitas, Ideologi dan Perilaku Pada Era Digital. Bandung: Simbiosa Rekatama Media.

Ningsih, N. A. P. (2014). Representasi Kekerasan Terhadap Transgender dalam Film Taman Lawang Skripsi. Diponegoro.

Prabasmoro, A. P. (2007). Kajian Budaya Feminis Tubuh, Sastra, dan Budaya Pop (cetakan ke). Yogyakarta: Jalasutra.

Rumata, V. M. (2020). Lesbi, Gay, Biseksual, Dan Transgender Dalam Bingkai Kajian Media Dan Komunikasi: Sebuah Kajian Literatur Sistematis.
Diakom: Jurnal Media Dan Komunikasi, 2(2), 168-177. https://doi.org/10.17933/diakom.v2i 2.64

Siti, R., Widiastuti, K., Risakotta, F. A., Syamsiyatun, S., Program, I. S., \& Mada, U. G. (2016). ProblemProblem Minoritas Transgender. Jurnal Ilmiah Sosiologi Agama Dan Perubahan Sosial, 10(2), 83-110.

Supanto. (2004). Pelecehan seksual sebagai kekerasan gender:antisipasi hukum pidana. $X X(3), 288-310$.

Tong, R. P. (2010). Feminist Thought: Pengantar Paling Komprehensif Kepada Aliran Utama Pemikiran Feminis (cetakan V). Yogyakarta: Jalasutra.

Utaminingtyas, E. C. (2013). Kekerasan simbolik media online (analisis framing berita fenomena LGBT dalam portal berita Republika Online). Interaksi Online, 5(3), 1-15. Retrieved from https://ejournal3.undip.ac.id/index.p hp/interaksionline/article/view/16623

Vida, H. D. (2011). Feminisme Dalam Majalah Perempuan. Jurnal Sociae Polites, Edisi Khus, 153-168.

Wood, Julia, T. (1994). Gendered Media: The Influence of Media on Views of Gender. Gendered Lives: Communication, Gender and Culture, 231-244. Retrieved from https://www1.udel.edu/comm245/re adings/GenderedMedia.pdf 
118 | Jurnal Komunikasi, Vol. 14 No. 02, September 2020: 105-118 